$\mathrm{PhD}$ in Law, Associate Prof., First Pro-Rector, Academy of the State Penitentiary Service, Chernihiv, Ukraine;

Pitiurenko V. I., master student of $351^{\text {st }}$ training group,

Academy of the State Penitentiary Service, Chernihiv, Ukraine

\title{
PROBLEMS OF THE LAW AND LEGISLATION SYSTEMS IN UKRAINE
}

The essence of the concepts of law and legislative systems, their correlation, as well as the current problems and tendencies of development of law and legislative systems in Ukraine are analyzed in the article. It is emphasized that the intensive development of modern social relations accordingly requires their effective and highquality legal regulation. It preconditions the necessity to optimize the process of reforming law and legislative systems of Ukraine aimed at ensuring the implementation of the proclaimed principles of a state governed by the rule of law, in which a person, his/her rights and freedoms are of the highest social value.

Key words: law system, elements of law system, legislative system, structure of legislative system.

Target setting. The law of any state is not just a set of rules of behaviour, but also a certain system of norms related to internal unity. This internal unity is conditioned by the essence of law, its principles, political and economic systems. In a modern state, the law must not only correspond to the general economic situation, but also to be an internally agreed expression that would not refute itself because of internal contradictions. The unity of law is determined by the nature, content and functions of law, which are objectively determined by the unity of social relations, forms of ownership, competition between individuals and different organizations. Therefore, the relevance of further scientific analysis of the main characteristics of the national legislative system, the state and ways of its improvement is not diminished, but on the contrary is increasing in modern conditions. Therefore, the study of the peculiarities and problems of the system functioning of legislation is the need of the present, which arises from the current level of legal knowledge, the needs of legislative activity and legal practice. 
Actual scientific researches and issues analyses. During the years of independence of Ukraine, domestic scientists have repeatedly addressed to certain questions of theoretical understanding of the laws of the system functioning of law and the legislation system of Ukraine. Significant achievement in the development of this problem were made by Alekseev S.S., Vasiliev A.S., Venherov A.B., Ivanov V.V., Kravchuk M.V., Mykolaenko A.I., Morozova L.A., Oleynikov S.M., Onishchenko N.M., Petryshyn O.V., Pohrebnyak S.P., Rabinovych P.M., Skakun O.F., Smorodynskyi V.S., Shahanenko V.P. and others.

Purpose setting. The purpose of the article is to analyze the state of the law and legislation system of Ukraine and to determine the main ways of its improvement.

The statement of basic materials. A characteristic feature of the modern society and the state functioning is the increasing role of law as the main form of foreign expression of law. In this context, the process of becoming and developing the statehood of an independent Ukraine is inextricably linked to the creation of new legislation. Legislation is a form of "life" of law. Legislation itself gives the rules of law formal certainty (one of the law feature).

National theory of state and law analyses the system of law through its structure, that is an internal structure that characterizes by the interaction of the rules of law of the respective state and their integration into legal institutions and industries. Rabinovych P.M. understands the system of all applicable legal rules of a particular state under the system of law [1, p. 105]. Onishchenko N.M., devoting a monographic study to the legal system, proposes such a definition of the concept of "system of law" - it is a structure of law, determined by economic and social structure, reflecting the internal coherence and unity of legal norms and at the same time their division into the relevant branches and institutions [2, p. 31]. Foreign Lawyer Morozova L.A. interprets the system of law as an objectively existing internal structure of law that is historically conditioned by the nature of the social relations that are govern [3, p. 273]. 
The system of law is a personalized systemic formation of society, because:

- is its functional system, its emergence, existence and development are conditioned by the conscious human needs for the organization, regulation and orderliness of public life, since the lack of these qualities makes it impossible for the stability, security and development of society, that is, its main conditions;

- is its institutional embodiment. This means that systematically organized, grouped legal norms are contained in normative legal acts, other sources of law, which give it a clear institutional structure;

- has a stable and dynamic character at the same time, thus providing the society with preservation, stabilization of its main relations, social order, and on the other hand, organizing and ordering their steady development;

- is related both directly and indirectly to the activities of other social entities - the state, its bodies - legislative, law enforcement, supervisory, etc., which perform functions in legal forms using certain methods.

Most domestic and foreign scholars understand the system of law:

- internal unity, organic interconnection and interaction of constituent parts of the state law, which reflects the unity of its constituent norms and distinguishes them into branches, sub-sectors and institutions;

- scientific construction that has a subjective basis, but there may be several of them at the same time;

- structure of law, determined by economic and social structure, which reflects the internal coherence and unity of legal norms, and at the same time their division into relevant branches and institutions;

- set of ordered and mutually agreed norms of law that characterize the internal structure of law.

It is possible to define the concept of "system of law" as an objectively existing structure of law are provided, within which the functioning of legal norms, institutions and branches of law, their interrelation and interaction, which are determined by the aims and objectives of the subject and method of legal regulation. It should be 
noted that the system of law as a dynamic phenomenon has tendencies of its development, in particular: the process of continuous accumulation of regulatory material and its distribution by industry and institutions; conditionality of the system of law by market relations; decentralization of increasing legal regulation; approximation of the system of Ukrainian law with international law.

Theorists note that the system of law consists of the following elements: the rule of law; Institute of Law; sub-branch of law (combining interconnected institutions formed within the same branch of law - suffrage within constitutional law, inheritance law within civil law); the field of law; subsystem of law (integrated by principles, tasks and functions, conditioned by the nature of interests set of institutions and branches of law governing the complex of public relations through the methods of legal regulation. Such subsystems are private and public law, procedural and substantive law, regulatory and protective law [4, p. 176-177].

The system of law and legislationo relate to each other in content and form. If the concept of the system of law characterizes the essential internal side of the objective law - its content, then the concept of the system of law reflects its outer side - that is the form [5, p. 250]. If the system of law is its internal structure, which corresponds to the nature of social relations that are subject to regulation, then the system of law is an external form of law, which expresses the construction of its sources, that is, the system of normative legal acts.

In our view, it is scientifically sound and correct to interpret the system of legislation solely as a coherent set of laws. In other words, the system of legislation is one of the forms of existence of rules of law, a means of organizing them, and combining them into such a variety of normative legal acts as laws. However, such an understanding is only possible at the theoretical level, since in fact the concepts of "system of legislation" are encompassed, including the Constitution of Ukraine, both laws and regulations based on them. However, the broad interpretation of the system of legislation as a set of all legal acts leads to a certain diminution of the value of laws in 
the system of legal acts and does not contribute to the establishment of the rule of law as the basis of law and order in the state.

As Venherov A.B. notes, the system of legislation is organized according to different objective criteria, conditioned by the needs of social regulation, the vital activity of society, a certain set of normative acts, which is formed for the most effective use of legal rules [6, p. 460]. That is not just a set of legal acts, but their differentiated system based on the principles of subordination and coordination of its structural elements [2, p. 86]. And how coherent and stable this system is, and how closely it is interrelated with its structural elements, how effective is the functioning of the legal mechanism that influences the formation and development of social relations in all spheres of life. Of course, this relationship has the opposite effect. That is, the general situation in the country, the level of economic and political development of the state significantly affect the stability of national legislation and its legal orientation.

The system of legislation of Pritchenko R.S. defines as a set of sources of law that are a form of expression of legal norms. In that view, law does not exist outside of legislation, law and legislation are correlated in content and form [7, p. 328]. Named scientist notes that if the law is considered as a collection of sources of law, it must be recognized that this concept covers not only regulatory acts, but also legal customs and legal precedents.

Skakun O.F. states that the concept of "system of legislation" can be interpreted in a "'narrow" and "broad" sense [5, p. 270]. Broad interpretation includes the notion of legislation acts of legislative institutions and by-laws (acts of governing bodies, etc.), and narrow interpretation - acts of legislative institutions (laws and regulations of parliament on the enactment of these laws). Skakun O.F. claims that legal science today is increasingly favored by a "narrow" interpretation of legislation, which is defined as a system of all country-specific laws, as well as international treaties ratified by its parliament [5, p. 271-272]. 
The structure of the legislative system is an internal subdivision of legislation into relatively separate groups of normative legal acts. The main elements of the structure of the legislative system:

- sectoral ("horizontal") - sectoral legislation (labor, civil, criminal, etc. legislation), that is, in the system of legislation subsystems of legal acts differ in the subject of legal regulation (for example, the subject of regulation of labor legislation - labor relations, as well as relations closely related to labor);

- hierarchical ("vertical") - laws and by-laws, that is, in the system of legislation subsystems of normative acts (laws, by-laws) differ in legal force.

A kind of hierarchical structure is the hierarchical structure of legislation in a federal state, the so-called "federal structure of legislation" - federal legislation and legislation of the subjects of the federation.

The system of legislation and the system of law, being paired categories, are included in a broader system of legal phenomena - the legal system. If the structure of the system of law is limited to norms, institutions, sub-sectors and branches of law, and the system of law also includes legislative arrays, then the legal system covers all legal phenomena, all legal reality [8].

It should be noted that in Ukraine today it is important to solve a complex of urgent practical issues of state building, first of all implementation of parliamentary, administrative and judicial reforms, legal, administrative-territorial and reform of local self-government. The strategy of these reforms is to overcome the crisis phenomena and end the transition period of the Ukrainian state, and consequently there is a growing need for the development of theoretical foundations of legislative, executive, judicial and other types of state power, a high level of scientific support for their reform, in forming a clear, an internally harmonized system of legislation. In the modern period, the legislation of Ukraine needs a comprehensive updating, a kind of purification. In general, we can distinguish the following tendencies of improvement and development of the system of legislation: firstly, it is the need to ensure the rule of legislation in all 
spheres of society, its stability and intensification; secondly, the specialization of legislation with its various forms of manifestation: differentiation, concretization, detailing; thirdly, legal unification and its related processes - integration, generalization, universalization, publication of complex regulations. If such a system of legislation is to be reconstructed, we are again convinced of the utmost importance of analyzing the historical processes of state and law-making in Ukraine to produce experience (whether positive or negative), and of the need for timely conclusions.

First of all, it is connected with the need for systematization of legislation, that is, the activities of state bodies aimed at streamlining and improving the legislation, bringing it into a logical, internally harmonized, harmonized system [9, p. 256]. Improvement and regulation of legislation is a characteristic feature of the process of development of a civilized rule of law. After all, the implementation of systematization promotes exemption from contradictory norms, elimination of obsolete norms in the legislation, legal loopholes. This, in turn, increases the effectiveness of the use of legislative acts, which accordingly influences the effectiveness of the influence of legislation on public relations and the quality of their legal regulation. Thus, the systematization of legislation is an effective tool to optimize the process of creating a quality legislative framework that is in line with the interests of civil society. Another positive meaning of systematization of legislation has also another aspect. It promotes the availability of legislation, which is extremely important in terms of its correct application, as well as the relevance of legal education and enhancement of the legal culture of the population.

Reformation of current legislation should be professional and meaningful, aimed at creating and providing an effective mechanism for legal regulation of all sides in public life. Only this approach will ensure the formation of law as the highest cultural value of society. And the legislation will be the only, effective and unified regulator of the existing public relations, which in turn will ensure the true implementation of the proclaimed principles of the rule of law and civil society. 
Given the need to improve the system of law and the system of legislation of Ukraine, it is possible to distinguish the basic elements of this process, namely: quality, efficiency, harmonization, systematization and globalization of legislation. Each structural element exerts its respective influence on the formation of new and change of existing regulatory acts, and determines the specific direction of improvement of legislation, the key in which should be not the quantity, but the quality of the adopted acts. Improving the level of legislation is raising the level of information impact on citizens` awareness through lectures, conferences, seminars, etc. It is also necessary to promulgate legislation before they are adopted, including possibly creating a website, a free publicly available mobile app for smartphones where draft legislation will be publicly read and only then passed by the legislator. Another necessary solution to the problem is the intensification of social dialogue between the legislator and the citizens of the country as a tool through which it is possible to achieve reduction of social and economic inequality. And most important is reviewing each sector of legislation separately to further align them with the requirements of the European Union.

Conclusions. Summing up, we can draw the following conclusions:

1. The system of law is an internal structure of law, which is expressed in the unity and consistency of all applicable rules of law of a given state, as well as in their distribution by branches and institutions of law. The structure of the system of law is an objectively existing internal structure of the law of a given state, which consists of the following elements: the rule of law, the institute of law, the branch of law, the section of law, the subsystem of law.

2. In the theory of law the system of legislation is understood as a set of normative legal acts of different legal force, which on the basis of the need to solve the problems facing the state have coherence of actions and internal unity. The main characteristics of this system is that it appears as a more subjective system, since it depends on the will of the legislator, it is a form of expression of law. The structure of the legislative system is an internal subdivision of legislation into 
relatively separate groups of normative legal acts. There are two elements to the structure of the system of law: sectoral ("horizontal") and hierarchical ("vertical"). The system of law and the system of legislation are not identical.

3. In today's context, the need to improve the system of law and the system of legislation in Ukraine becomes particularly important. Improvement of the system of law and the system of legislation is essentially a process aimed at ensuring the constant conformity of its elements, from the initial - normative prescription, to the really existing social relations. The constant development of economic, political, social and other relations requires that the legislator optimally considers these qualitative changes in legislative activity, which in turn brings to life both individual legislative acts and entire sections of legislation. The process of harmonization of national legislation with international law is still relevant and is, to a certain extent, a program of further development of the system of legislation of Ukraine.

\section{References}

1. Rabinovych, P. M. (2002), Fundamentals of the general theory of law and state, Konsum, Kharkiv.

2. Onishchenko, N. M. (2002), Legal system: problems of theory, V. M. Koretsky Institute of State and Law of the National Academy of Sciences of Ukraine, Kyiv.

3. Morozova, L. A. (2011), Theory of State and Law, Eksmo, Moscow.

4. Petryshyn, O. V. (Ed.) (2015), Theory of State and Law, Law, Kharkiv.

5. Skakun, O. F. (2016), Theory of State and Law: Encyclopedic course, Espada, Kharkiv.

6. Venherov, A. B. (1998), Theory of State and Law, New Lawyer, Moscow.

7. Vasiliev, A. S., Ivanov, V. V., Mykolaenko, A. I. and others. (2003), Fundamentals of theory of state and law in questions and answers, Odissei, Kharkiv.

8. Yermolenko, D. O. (2001), «Correlation of social and legal state», Entrepreneurship, economy and law, № 8, pp. 95-96.

9. Skakun, O. F. (2001), Theory of State and Law, Konsul, Kharkiv. 


\section{Олійник О. I., Пітюренко В. I. ПРОБЛЕМИ СИСТЕМИ ПРАВА І СИСТЕМИ ЗАКОНОДАВСТВА В УКРАЇНІ}

У статті проаналізовано зміст понять системи права та системи законодавства, їх співвідношення, а також сучасні проблеми й тенденції розвитку системи права і системи законодавства в Украӥні. Наголошено, щуо інтенсивний розвиток сучасних суспільних відносин відповідно вимагає ефективного та якісного їх правового регулювання. Це зумовлює необхідність оптимізації процесу реформування системи права та системи законодавства України, спрямованого на забезпечення реалізації проголочених принципів правової держави, де людина, ї̈ права та свободи є найвищую сочуільною циінністю.

Визначено поняття «система права» як об' єктивно існуючу будову права, в межах якої відбувається забезпечення функціонування правових норм, інститутів $і$ галузей права, їх взаємозв'язок та взаємодія, які зумовлені иілями та завданнями предмета й методу правового регулювання. Зазначено, шуо система права як динамічне явище має тендениї свого розвитку, зокрема: процес безперервного накопичення нормативного матеріалу та його розподіл за галузями та інститутами; обумовленість системи права ринковими відносинами; децентралізачія правового регулювання, щзо посилюється; зближення системи украйнського права з міжнародним правом.

Наголошено, щз реформування чинного законодавства повинно бути професійним та змістовним, спрямованим на створення та забезпечення ефективного механізму правового регулювання всіх сторін суспільного життя. Лише такий підхід забезпечить формування права як найвищої культурної иінності суспільства. А законодавство буде тим єдиним, дієвим та уніфікованим регулятором існуючих суспільних відносин, що у свою чергу забезпечить дійсну реалізачію проголочених принципів правової держави та громадянського суспільства. Зважаючи на необхідність удосконалення системи права та системи законодавства Украӥни, виокремлено основні елементи цуього процесу, а саме: якість, ефективність, гармонізачію, систематизацію та глобалізацію законодавства.

Ключові слова: система права, елементи системи права, система законодавства, структура системи законодавства. 